\title{
1. \\ Before Sarcophagi
}

\section{Glenys Davies}

Elaborately decorated sarcophagi came into use in the city of Rome and its environs from c. 120 onwards. ${ }^{1}$ Only a handful of sarcophagi can be dated to the first century or first two decades of the second century, the best known of which is perhaps the very early and anomalous Caffarelli sarcophagus in Berlin (c. 40). ${ }^{2}$ Of the three early sarcophagi illustrated here two belong to the Trajanic period (i. e. between c. 100 and 120) (Figures 1.8 and 1.9), and the third (Figure 1.10) is Hadrianic. ${ }^{3}$ Inhuming the unburnt body in a sarcophagus was at this time an exceptional form of burial, presumably undertaken for personal or family reasons, and it would not be seen as the usual Roman funerary custom at the time. ${ }^{4}$ Instead the dead were usually cremated, and the funerary monuments of choice for those who could afford them were the marble ash chest (designed to hold the cremated remains taken from the pyre), the grave altar (which did not have a cavity inside to hold the ashes and therefore had a more purely commemorative function) or the ash altar (which was larger in size than an ash

1 The date at which production of the main series of imperial sarcophagi began will be discussed in more detail below.

2 Caffarelli sarcophagus, now in the Pergamon Museum, Berlin (inv. SK 843a): ASR VI, 2, 1,77 , no. 1. Although this sarcophagus is decorated with garlands its style is quite different from that of the Trajanic and Hadrianic series of garland sarcophagi which belong to the beginning of the vogue for using sarcophagi in the second century.

3 Sarcophagus of C. Bellicus Natalis Tebanianus (Figure 1.8), Camposanto, Pisa: ASR VI, 2, 1, 79-81, no. 6 (dated c. 100); child's sarcophagus with biographical scenes (Figure 1.9), Museo Nazionale Romano inv. 65199: ASR I, 4, no. 190, pl. 45, 1-5 (c. 100); Huskinson 1996, 10 and 22, no. 1.29 (c. 120); child's sarcophagus with griffins in Ostia with inscription to Ostorius Ostorianus (Figure 1.10) (Ostia Museum inv. 1156): Huskinson 1996, 63, no. 9.14; Eberle1990, 53, fig. 2; Herdejürgen 1990, 97-8, fig. 2 $(130-40)$.

4 Herdejürgen suggests that only 15 garland sarcophagi can be assigned to the period from Augustus to c. 120, and that literary sources provide three possible reasons for the choice of such an anomalous form of burial: being a member of a Pythagorean sect, family tradition, and sensitivity to the burning process (ASR VI, 2, 1, 17). Petronius (Satyricon 111.2) describes inhumation as a Greek custom, and Tacitus (Annals 16.6), commenting on the exceptional practice of embalming used for Poppaea, says that cremation was the Roman custom. 
chest, and combined the functions of both ash chest and grave altar). ${ }^{5}$ The change from ash chests and grave altars to sarcophagi, and from cremation to inhumation, took the best part of a century to achieve, but by the early $3^{\text {rd }}$ century the practice in Rome had completely reversed: the usual form of funerary monument for those who could afford it was the sarcophagus, and ash chests and grave altars had practically disappeared. ${ }^{6}$ Whereas in the early empire tombs were built to accommodate cremated remains only, in the $3^{\text {rd }}$ century they were designed to contain inhumed bodies, whether these were placed in sarcophagi or more basic forms of coffin or trench grave. ${ }^{7}$ This chapter examines issues concerning this change in practice by focussing on the decoration of the monuments themselves. It concentrates on the types of funerary containers and monuments that were used before sarcophagi arrived and those sarcophagi which can be dated to the earliest decades of the second century: it considers the salient differences between them, and asks whether we can ever confidently answer the question of why the changes took place.

\section{The nature of the question}

When this phenomenon was considered in the early and mid twentieth century it was assumed that the reason for such a change in burial practice should be sought in the area of religious belief, and that the explanation must involve changes in beliefs about and attitudes to the fate of the body and soul after death. Even A.D. Nock's article on inhumation and cremation published in 1932, which argued that the change was one primarily of 'fashion', examined the question from the point of view of the attitude of different religious groups

5 For these monuments see Altmann 1905, Sinn 1987, and Boschung 1987.

6 As Jaś Elsner has pointed out to me, it is an assumption (if a plausible one) that sarcophagi represent inhumation as a burial rite: the size and shape of sarcophagi leads to the supposition that they were designed to, and always did, contain unburnt and fully articulated bodies, but the form of the human remains inside is not known for most sarcophagi. It is conceivable that on occasion they might have contained ashes or a secondary deposit of bones. Some cases of ashes placed in sarcophagi have been recorded, but these are generally at sites outside the city of Rome or at periods later than that considered here (Toynbee 1971 and 1982, 40 and n.107; Nock 1932, 333 and n.61). From the available evidence it does seem that there was a general correlation between sarcophagi and inhumation, but this is a particularly pertinent issue when considering 'children's sarcophagi' which are often defined as such by size (see below, n. 76).

7 This change can be seen particularly clearly in the excavated cemeteries under the Basilica of St. Peter in the Vatican and in the Isola Sacra near Ostia, where tombs of the later $2^{\text {nd }}$ century provided for both cremation and inhumation, and contained both ash containers and sarcophagi.. For a brief discussion of the evidence see Morris 1992, 56-62; for details of the tombs, Toynbee 1971 and 1982, 132-143. 
to death and the afterlife. Franz Cumont's monumental study of Roman funerary symbolism (1942) interpreted the decoration of Roman funerary monuments as expressions of complex and deeply held afterlife beliefs and hopes. Nock, in his review of Cumont, and in line with his previous article, queried the idea that the majority of those buying sarcophagi held or were trying to express such complex religious/philosophical beliefs. ${ }^{8}$ Some scholars, however, were persuaded by Cumont's approach and adopted it enthusiastically in their analysis of specific monuments, ${ }^{9}$ while others instead developed a more general approach to funerary symbolism which toned down some of Cumont's more extravagant arguments but nevertheless assumed that the motifs used should be explained primarily in relation to afterlife belief. ${ }^{10}$ Nock's scepticism nevertheless struck a cord with many, and scholars studying these monuments in the later part of the $20^{\text {th }}$ century have on the whole tended to react against Cumont's interpretations, seeing them as too often resting on obscure texts and arcane philosophies unlikely to be known by the public at large.

Even so, many would agree with Toynbee when she states that: 'The view that mere fashion or a purely ostentatious taste for elaborate and expensively decorated coffins could have brought about a change in burial rite so widespread and lasting is not convincing. ${ }^{11}$ Instead she suggests that 'it is in the development of this "other-worldly" thought that we have to seek the reason for the striking and enduring change in the method of disposing of the dead'. ${ }^{12}$ Toynbee's idea that the use of inhumation is 'somehow a gentler and more respectful way of laying to rest the mortal frame ${ }^{13}$ is echoed by McCann who considers, but rejects, the idea that the production of sarcophagi was inspired by the emperor Hadrian's taste for Classical forms, which resulted in an influx of

8 Cumont 1942; Nock 1946. On the whole Cumont deals with later Roman monuments, but he does discuss the ash chest of T. Flavius Abascantus in some detail in an Appendix, and the ash chest of Ti. Claudius Vitalis in the text (Cumont 1942, 162-8).

9 See, for example, the interpretation of the decoration of the ash chest of Ianuaria (now in the Museo Gregoriano Profano, inv. 9858/9) in Farnoux 1960, and of the ash chest of Volusia Arbuscula (in the Musée Condé, Chantilly) in Berard 1974, 15. Cumont's views continue to be more highly regarded by French-speaking and Italian scholars, while English and German speakers tend to be more sceptical or dismissive of his approach.

10 See especially the work of Toynbee. For example, Toynbee writes that: 'A charioteer winning a race on a tombstone, or a hunting- or battle-scene on a sarcophagus, speak of the soul's triumph over death and evil; a man or woman reclining at a banquet expresses the soul's endowment with heavenly bliss' (Toynbee 1956, 210). I discuss the issue of different approaches to the symbolism of the decoration of ash chests and grave altars more fully in Davies 2003.

11 Toynbee 1971 and 1982, 40. But Toynbee adds 'despite the fact that ashes have occasionally been discovered in sarcophagi'.

12 Toynbee 1971 and 1982, 33.

13 Toynbee 1971 and 1982, 41. 
artists from Asia Minor to Rome: 'Artistic considerations may in part explain this change, but concern with inhumation of the body and the wish to honour it with a more sumptuous and lasting home must reflect more than a change in fashion and taste.. 'Fashion', however, is increasingly seen by many modern social historians as something that should not be considered too trivial for academic study - as the phrase 'mere fashion' implies - but rather as a phenomenon worthy of study in its own right, revealing many insights into the thought and concerns of the culture that created it. Thus recent studies have tended to focus on the ways the monuments express identity and status rather than afterlife belief: the focus has switched to social rather than religious reasons for commissioning and buying expensive and elaborately decorated funerary containers and monuments. The switch in interest can be seen clearly, for example, in the contrast between Cumont's interpretation of the scene on the grave altar of Flavius Abascantus showing him (presumably) reclining holding a cup as a 'festin célèste', a banquet taking place in a celestial afterlife, with Roller's recent assessment of the scene of C. Calpurnius Beryllus (see Figure 1.6) reclining on a couch with a table in front and a serving boy at either end as an expression of his social aspirations. ${ }^{15}$

At the same time important work was being done on the typology and chronology of the monuments, and on catalogues which considerably enhanced the known corpus of material for study, refined their chronology, and began to identify workshop groupings. ${ }^{16}$ Such studies have tended to be rather cautious in their consideration of the significance and in particular the symbolic content of the decoration of the monuments; moreover, the various types of monuments have generally been considered in isolation, rather than in relation to one another. It is this relationship that this chapter aims to explore.

No surviving ancient text discusses, let alone explains, the change in burial rite and type of funerary monument that occurred in Rome in the $2^{\text {nd }}$ century (which might in itself suggest that contemporary Romans did not see the change in burial rite as of particular significance or interest). In the absence of any such

14 McCann 1978, 20. The idea that Hadrian's Hellenism was an important factor in the introduction of inhumation to Rome is reconsidered positively in Morris 1992, 53-61.

15 Cumont 1942, 457-462. He interprets the wreath often held by the reclining figure as a 'couronne d'immortalité', and the little winged boy flying above Abascantus' legs holding a torch as Phosphorus, who 'shows the heroised dead the pathway in the sky' (Cumont 1942, 458). For the discussion of the altar of Calpurnius Beryllus see Roller 2006, $31-$ 37; for him the 'banquet' scene evokes 'high-style elite conviviality', while 'certain details assert a freedman's achieved status and belonging' - 'The message for the viewer, correspondingly, is one of both social differentiation and social integration' (Roller 2006, 36).

16 Sinn 1987 for ash chests; Boschung 1987 (which provided an update on Altmann 1905); ASR VI, 2, 1 for garland sarcophagi. 
literary evidence the main source of information is the monuments themselves. The first question I shall be considering therefore is the extent to which the decoration of ash chests and grave altars differs from that of the earliest sarcophagi: was there a complete break in pictorial tradition, or was there continuity? Can we discern changes in the motifs and designs used which might suggest significant changes in concerns and attitudes? Another set of questions, which are more difficult to answer given the available information, concerns the people who were buying or commissioning the monuments. What kinds of people elected to use the new monuments, and, once sarcophagi had become well-established, who were the most likely to hold onto the old monuments and methods of burial? Equally important to consider are the suppliers of the monuments - the sculptors who made them: to what extent were they responsible for creating or fostering the demand for a different type of monument? Were sarcophagi made in the same workshops as grave altars and ash chests? Or were sarcophagi promoted by new workshops (possibly indeed by sculptors newly arrived in Rome from the eastern provinces), or by workshops which had hitherto specialised in non-funerary art (such as the sculpted decoration of temples and other public buildings)? And finally, what was the motivation that inspired an individual's decision to be inhumed (or to inhume a relative) in a sarcophagus rather than be cremated and commemorated by a grave altar and/or an ash chest? Which was the more important factor in making the decision: the burial rite or the type of monument?

\section{Dating and chronology}

Only a very small proportion of the monuments can be dated at all precisely. As the majority of ash chests and grave altars have inscriptions which provide some information about the person or people commemorated it might be expected that these would give some fixed dates on which a chronology could be based. But the date of death is only very rarely mentioned: Boschung lists only six altars which give the names of the consuls at the time of death. ${ }^{17}$ Very few of the people concerned were famous enough for us to know the date of their death from other sources, and any other information provided can usually only suggest an approximate date of death: the best we can hope for from the inscriptions is a 20-year period in which the person commemorated is likely to have died. Occasionally we know the date of events in the deceased's life (e.g.

17 Boschung 1987, 57-8, Appendix I, nos. I.1-I.6. The grave altar of Volusia Prima and Volusia Olympias in the Villa Albani (Boschung 1987, 57, no. I.1), for example, has inscriptions on the sides naming the consuls of 89 and 97 (CIL VI 9326). This altar is richly decorated and belongs to the period of particular interest to this chapter. 
the date of a consulship), but not how long after that date the person concerned died: this is true of two of the monuments illustrated here, the sarcophagus of C. Bellicus Natalis Tebanianus, who was consul in 87 (Figure 1.8), and the grave altar of Licinia Magna, who was the daughter of a consul of 27 and wife of a consul of 57 (Figure 1.2).$^{18}$ Many ash chests, too, are dedicated to imperial freedmen whose names indicate the regime or even the emperor who granted their freedom - but again this provides only a terminus post quem, with a long potential survival period after that (although this may be limited to some extent by the stated age at death, and likely lifespan). ${ }^{19}$ The presence of portraits with fashionable hairstyles is also evidence that can be fairly closely dated, but again only quite a small proportion of the corpus has this feature. ${ }^{20}$ The early sarcophagi are even less helpful in that very few of them have inscriptions or portraits. Occasionally the context in which the monument was found provides some clue about the date of the monument, such as the brick stamps in the structure of the tomb with three sarcophagi in it found at the Porta Viminalis: these date the construction of the tomb to c. 134, but this provides only indirect evidence for the dates of the sarcophagi (which might have been made some

18 Tebanianus, consul in 87 , may have died soon afterwards, but may well have survived into the reign of Trajan, or even have died early in the reign of Hadrian: Herdejürgen's date for his sarcophagus of c. 100 seems rather too early to many, including the present author (ASR VI, 2, 1, 22-23). Eberle 1990, 50 for example suggests that Tebanianus died c. $120-125$. See also the section on dating with the help of prosopography in Boschung's appendix I (1987, 58-63): coincidentally, two other inscriptions name consuls of 87 - one is the grave altar which commemorated C. Calpurnius Crassus Frugi Licinianus who probably died in the reign of Hadrian (Boschung 1987, no. 856 and appendix I.10; CIL VI 31724); the other names a L. Volusius who was the husband of Licinia Cornelia Volusia Torquata and who seems also to have been consul in 87 (Boschung 1987, no. 13 and appendix I. 15; CIL VI 31726). The circumstances which date the altar of Licinia Magna are also discussed in Boschung 1987, 58-9, no. I.17: he suggests the altar dates to c. 80 (Boschung 1987, 97, no. 657).

19 So, for example, someone who has the nomen Flavius and who is described as an Augusti libertus cannot have died before 69, but equally he could have outlived the Flavian dynasty by several decades and could easily have survived into (even beyond) the reign of Hadrian. Some limitation to the likely date of death may be provided if the inscription gives the age at death. Similar calculations can sometimes be made for slaves and freedmen of other families whose members held consulships: the best studied of these is the large group of funerary monuments for the household of the Volusii Saturnini, a family which provided several consuls over the course of the first century (Boschung 1987, 62-3, App. I.49-I.61; Buonocore 1984).

20 The grave altars with portraits have been collected and studied in Kleiner 1987. Many such altars however make such a feature of the portrait itself that there is little other decoration, which means that they do not provide as much information about the stylistic development of other features as one might wish. The female hairstyles on the sarcophagus illustrated here in Figure 1.9 are important evidence for its date in the Trajanic period. 
time after, or indeed before, the tomb was built), but does at least give a broad indication of the period concerned. ${ }^{21}$

Frustratingly imprecise though all this information is, it does provide a rough chronological framework on which various scholars have built complex and detailed chronologies for the groups of monuments concerned. To fill in the gaps in the chronology and to assign specific pieces to their place within the framework scholars have relied primarily on the assessment of their style and of the direction and speed of stylistic development within the corpus. ${ }^{22}$ In the absence of more objective criteria this system has worked reasonably well and has resulted in what appear to be convincing and remarkably coherent dates for the series of ash chests, grave altars, and garland sarcophagi, ${ }^{23}$ but it should be recognised that there is a fair amount of subjectivity involved in coming to these conclusions, with consequent room for disagreement. Herdejürgen's method, for example, relies heavily on the assumption that there were recognisable and rapidly evolving period styles, and that sculptors working at the same time, even in different workshops, would share the same definable stylistic characteristics but at the same time she acknowledges that individual workshops had their own quirks. ${ }^{24}$ It is not always as easy as some would maintain to decide which characteristics belong to a workshop and which to a period, and different scholars interpret the stylistic evidence in different ways. Thus the absolute dates that are assigned to an individual piece by two different scholars may be quite different, and it has to be recognised that the dates cited in most cases are relative rather than absolute, and they should be regarded as useful guidelines rather than definitive in any sense. Nevertheless, in seeking to understand why some Romans chose to be buried in sarcophagi rather than be cremated and

21 Three sarcophagi were found in this tomb: the garland sarcophagus placed opposite the door of the tomb was probably the earliest burial, but can the sarcophagus also be securely dated to the years around 134? (ASR VI, 2, 1, no. 78 dates it 130-140;ASR V, 2, 3, 91, no. 124 dates it (or, rather, its lid) to c. 120). And how much later should we date the other two sarcophagi (both mythological frieze sarcophagi, one decorated with the death of the Niobids and the other with the Orestes story)? Indeed, even within the same book (Zanker and Ewald 2004) the Niobid sarcophagus is dated 'after the middle of the second century' (captions to figures 28 and 29) and 'c. 130-140' (359), and the Orestes sarcophagus to c. 150 (caption to fig. 62) and 130-140 (364).

22 Early and pioneering work was done, for example, on the stylistic development of garlands: Toynbee 1934 established that the main series of garland sarcophagi belonged to the Hadrianic period and were not Augustan as had previously been thought, and Honroth 1971 continued the study by comparing the garlands on undated funerary monuments with more closely dated reliefs in both state and funerary art.

23 Sinn 1987; Boschung 1987; ASR VI, 2, 1.

24 See for example Herdejürgen 1990, where she identifies a number of workshops making garland sarcophagi at Ostia, but maintains that, although their decorative repertoires and styles were distinct from those of metropolitan Roman workshops, they did not have enough in common with each other to constitute a distinctive Ostian style. 
commemorated by an ash chest or grave altar, and why this change in burial practice might have caught on more generally, we have to have some idea of what was being produced when.

In this chapter I shall be looking specifically at those ash chests and grave altars which have been dated to the end of the first and beginning of the second century, and the earliest of the main series of the sarcophagi made and used at Rome (and its environs, especially Ostia). If one looks at the catalogues of sarcophagi in the Antiken Sarkophagreliefs (ASR) series it becomes clear that very few sarcophagi are assigned dates before 150 , but that a much larger number fall into the bracket of c. 150-160, or are described as early-mid Antonine (some authors prefer to use absolute dates, albeit covering quite wide periods of time, while others are more comfortable with periods expressed in terms of the ruling emperor or dynasty). Clearly the general consensus is that until c. 150 the use of sarcophagi could be considered experimental and unusual, but that around or shortly after 150 a much larger number of people were opting to use them, and workshops were established which were sufficiently familiar with sarcophagi that they had begun to make standard designs. (I leave open for now the question of whether these were the same workshops that had up until then made ash chests and grave altars or were new workshops that were created to provide for a new form of demand).

\section{Schemes and themes of decoration: ash chests and grave altars}

The decorative repertoire for ash chests and grave altars (and the hybrid ash altars) evolved over the course of the first century: a general trend was simply for the addition of more motifs, but some items went in and out of fashion. ${ }^{25}$ Although there were always some very plain monuments, and also some idiosyncratic pieces that were presumably specially commissioned and had special meaning for the commissioner, for the majority there was a large repertoire of commonly-used motifs which could be combined in a large number of different ways, to the extent that it is difficult to find any two monuments decorated in exactly the same way. The possible decorative schemes can be divided into two broad categories: those based on the hanging garland and those which rely on more architectonic motifs, particularly columns or pilasters at the corners. Examples of the garland variety illustrated here are the

25 This can be seen, for example, in the changing preferences for garland supports: bucrania were used early on but became less popular in the later first century, only to experience a revival in the Hadrianic period. Their place had been taken successively by rams' heads, the head of Jupiter-Ammon and cupids (erotes) - each of these had its period of greatest popularity. 
grave altars of Licinia Magna (Figure 1.2), ${ }^{26}$ of L. Aufidius Aprilis (a corinthiarius or bronze-smith who worked in the area of the Theatre of Balbus) (Figure 1.3), ${ }^{27}$ and of T. Apusulenus Caerellianus (Figure 1.5), ${ }^{28}$ all three of which have been dated to the late Flavian period; the architectonic variety is represented by the ash chest of L. Lepidius Epaphra (Figure 1.1), ${ }^{29}$ the ash altar of Ti. Claudius Callistus (Figure 1.4), ${ }^{30}$ and the grave altar of C. Calpurnius Beryllus (Figure 1.6). ${ }^{31}$ Both types of decorative scheme involve combining a variety of individual motifs in a design which is symmetrical and emphasises the front of the monument - indeed in most cases the attention of the viewer is drawn to the inscription in a panel placed in the centre of the upper part of the front.

Standard motifs on the garland variety include the garland itself (made up of fruit and flowers, laurel or oak leaves, or occasionally other plants) slung from bulls' skulls (bucrania), rams' heads or the head of Zeus/Jupiter Ammon, or from other supports such as cupids (erotes), torches or candelabra at the upper corners of the front: there might be other items under the front corner supports, such as eagles, swans, sphinxes or griffins (the dancing figures on the grave altar of L. Aufidius Aprilis, seen in Figure 1.3, are unusual), and small garden birds, insects and lizards are often shown around the garland. The small semi-circular space above the garland, which was just under the inscription panel and near the centre of the front, was often the location for a less standard, perhaps more personally chosen and meaningful, motif such as a small mythological or animal scene or a portrait, but a popular motif was the head of Medusa, sometimes flanked by swans (as on the grave altar of Licinia Magna, see Figure 1.2). The sides of such monuments would often be decorated in a similar way, but usually without the more complex scenes and commonly (especially on the grave altars)

26 Grave altar of Licinia Magna, Vatican Museums, Gabinetto delle Maschere 811: Altmann 1905, 36, no. 3; Boschung 1987, 97 no. 657, pl. 18; CIL VI 1445/31655.

27 Grave altar of L. Aufidius Aprilis, discovered in 1965 on the Via Flaminia, now on display in the Crypta Balbi museum: Caronna 1975, 205-214; Panciera 1975, $222-$ 229 (inscription); Boschung 1987, 99, no. 693, pl. 34.

28 Grave altar of Apusulenus Caerellianus, Museo Nazionale Romano inv. 23892: Boschung 1987, 102, no. 754, pl. 30; CIL VI 38027.

29 Ash chest of Lepidius Epaphra, British Museum 2368: Sinn 1987, 132, no. 161; CIL VI 21188. Sinn dates this late Claudian-Neronian.

30 Large ash chest or ash altar of Ti. Claudius Callistus, an imperial freedman: this monument was found on the Via Flaminia placed back to back to and on the same base as the altar of Aufidius Aprilis. The inscription on the base shows that it was only Aprilis's altar that was originally intended for this site. It too is now on display in the Crypta Balbi museum. Caronna 1975, 214-222; Panciera 1975, $231-2$ (inscription); Boschung 1987, 104, no. 782, pl. 35.

31 Grave altar of C. Calpurnius Beryllus, Capitoline Museum inv. 1967: Altmann 1905, no. 182; Boschung 1987, 107, no. 830, pl. 42; CIL VI 14150. 


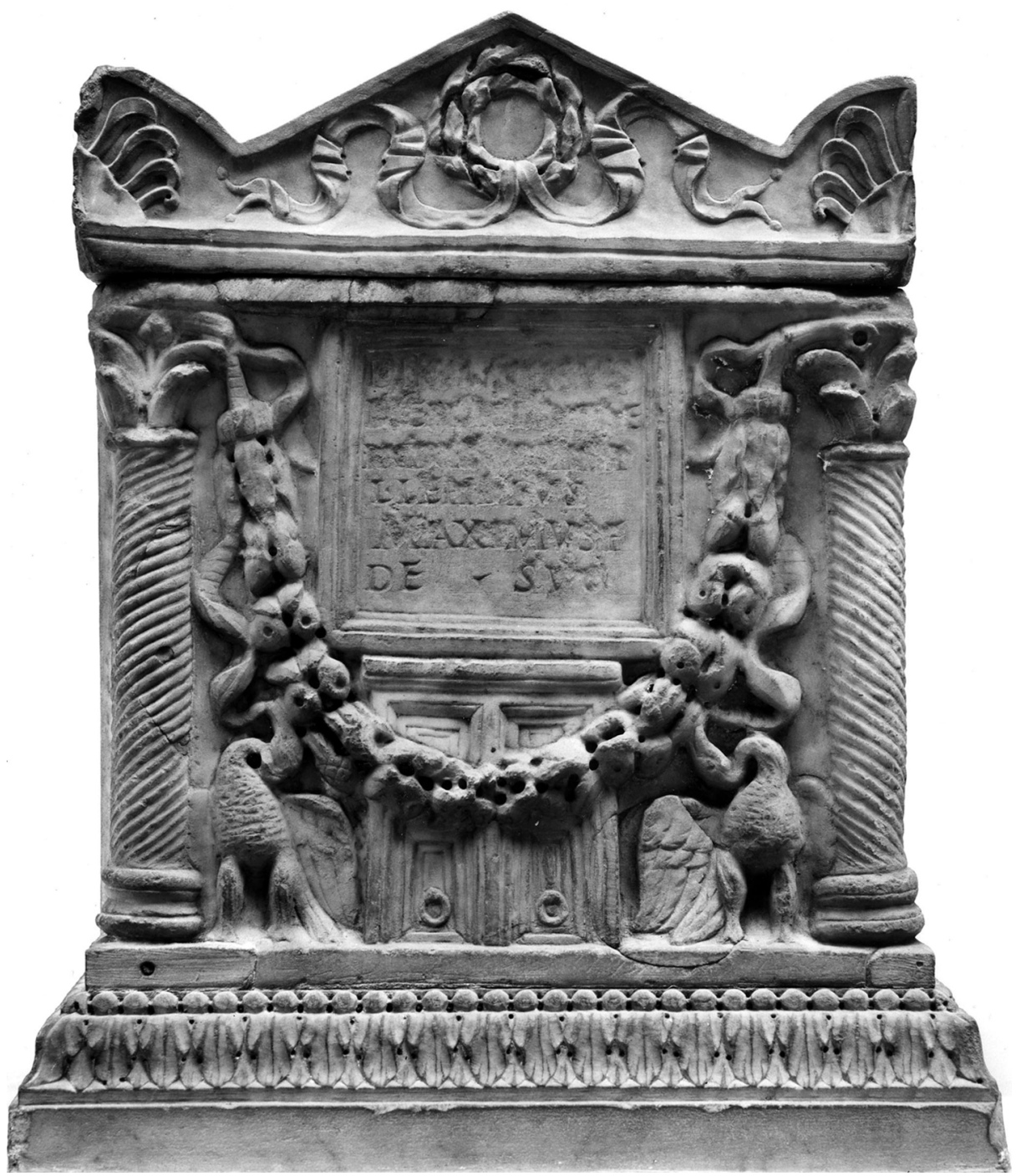

Figure 1.1: Ash chest of L. Lepidius Epaphra in the British Museum (2368) (late ClaudianNeronian). Photograph: (C) The Trustees of the British Museum.

with a jug and an offering bowl (patera) above the garlands: these are objects associated with making offerings to the gods and to the dead. ${ }^{32}$

32 Several authors have pointed to the importance within the repertoire used on grave altars, ash chests and some early sarcophagi of motifs associated with sacrifice and religious ritual in general: in addition to the jug and patera the garlands themselves could come into this category, especially when combined with bucrania. Such motifs could refer to 


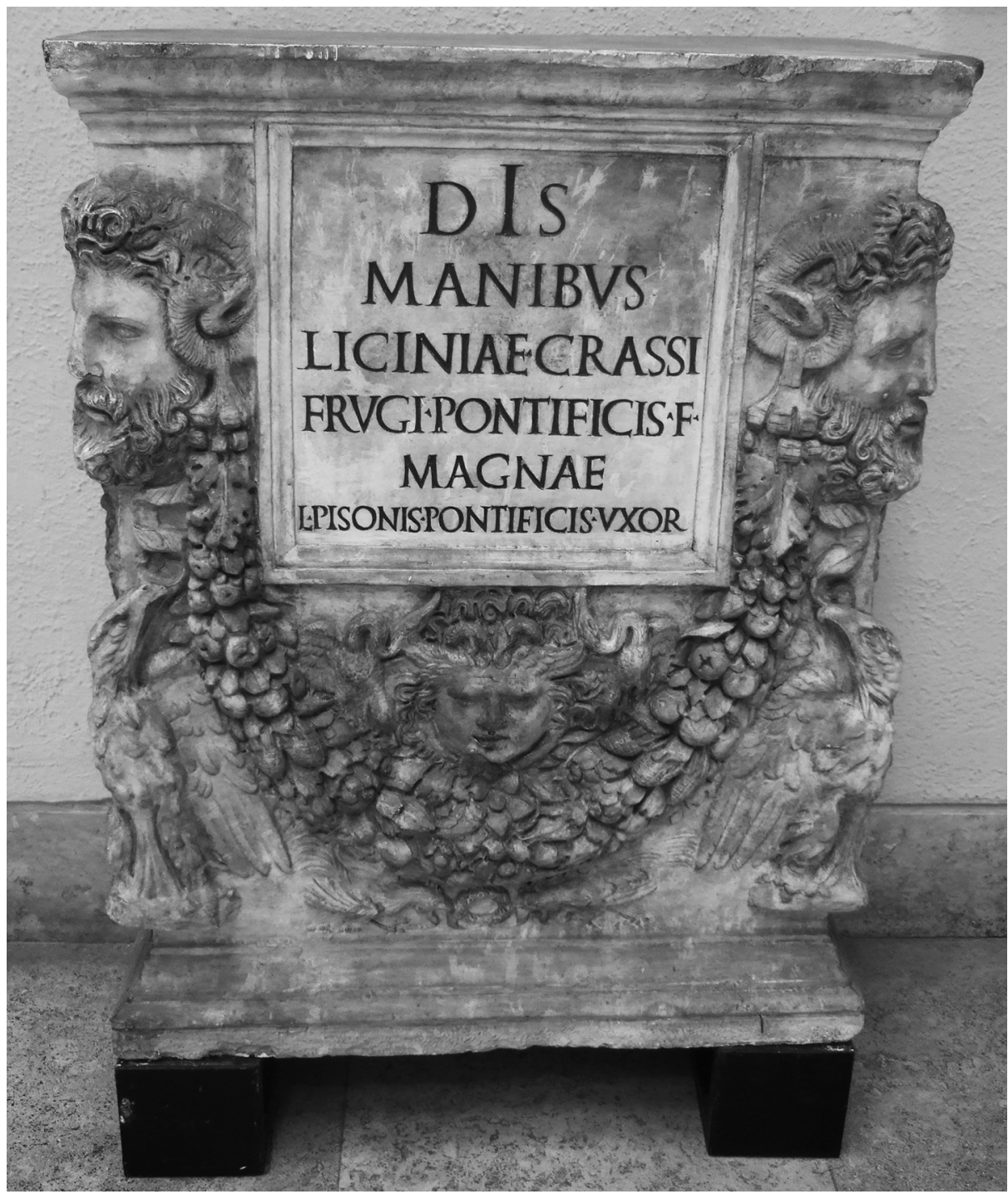

Figure 1.2: Grave altar of Licinia Magna. Vatican Museums, Gabinetto delle Maschere 811 (AD 70-80). Photograph of the cast in Civiltà Romana Museum, EUR, by the author.

Standard motifs to be found in the 'architectonic' format include those designed to make the monuments look like a building, such as columns and pilasters (usually placed at the corners and so flanking the inscription panel on the front), imitation ashlar masonry, doors and niches (aediculae) (see the closed

the cult of the Dii Manes or to the piety of the deceased (or , of course, both). Boschung 1993, 38; ASR VI, 2, 1, 24; Morris 1992, 44. 


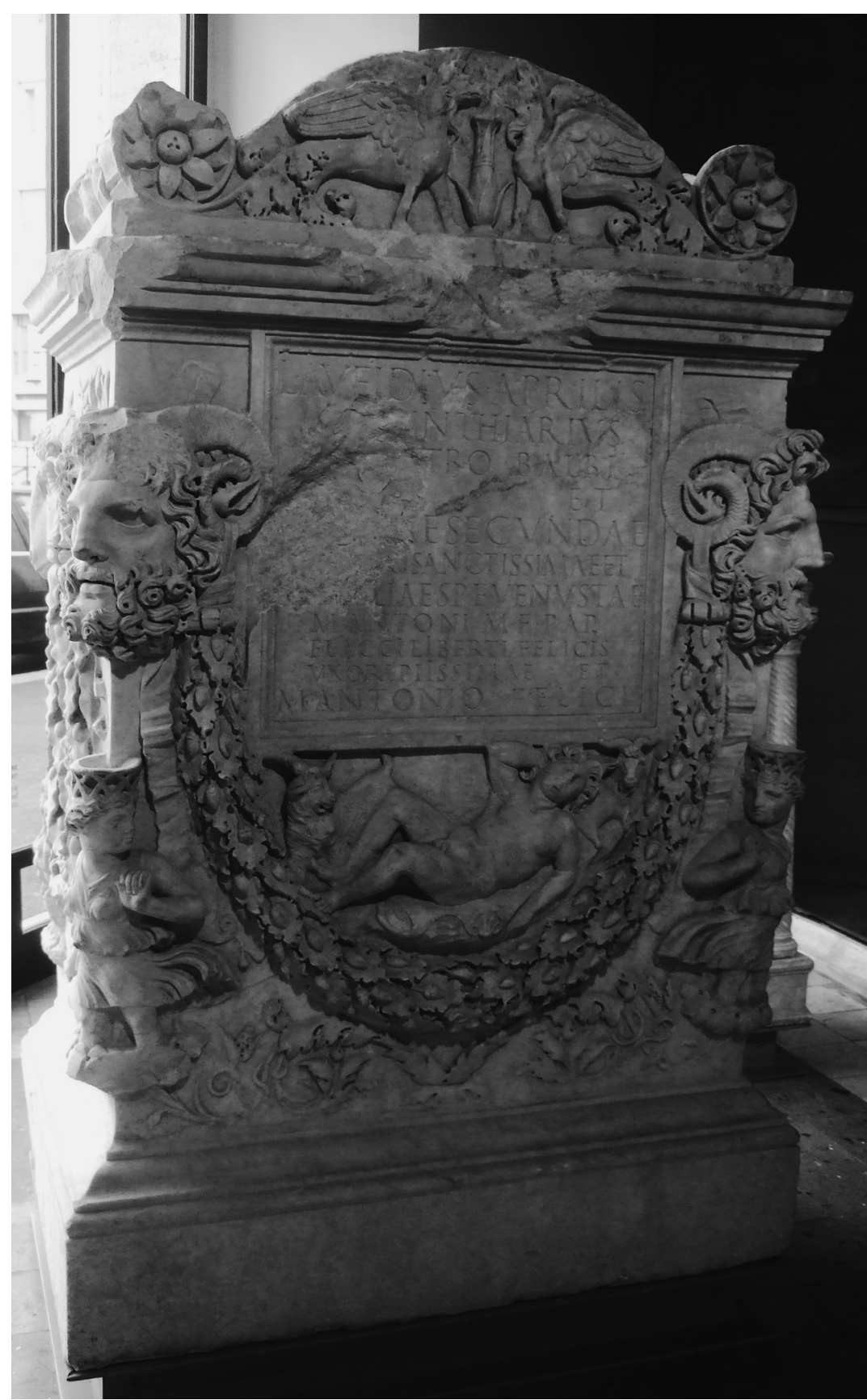

Figure 1.3: Grave altar of L. Aufidius Aprilis in Crypta Balbi (found on Via Flaminia) (late $1^{\text {st }}$ century AD). Photograph: author. 


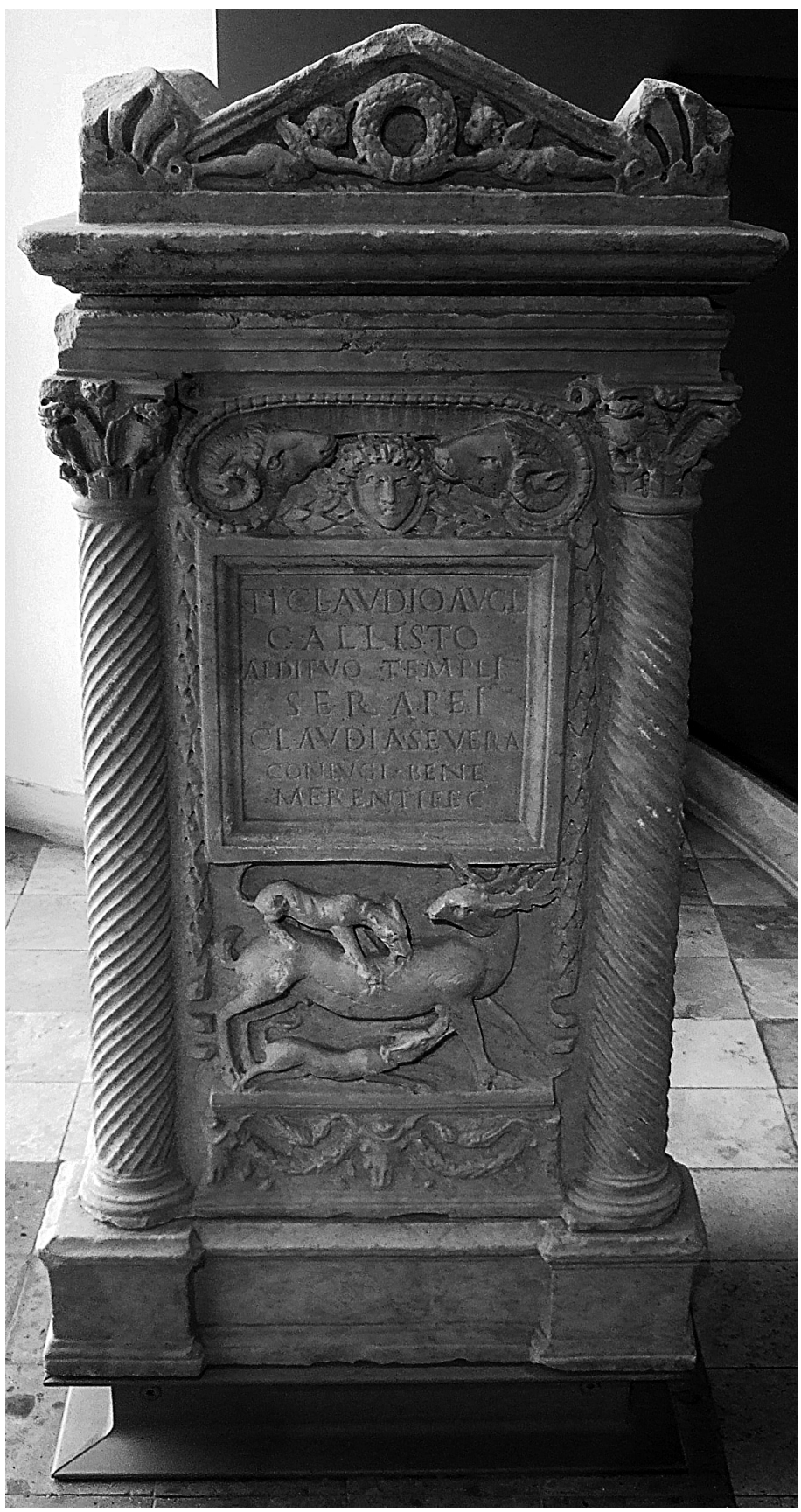

Figure 1.4: Large ash chest of Ti. Claudius Callistus in Crypta Balbi (found on Via Flaminia) (late first century AD). Photograph: author. 


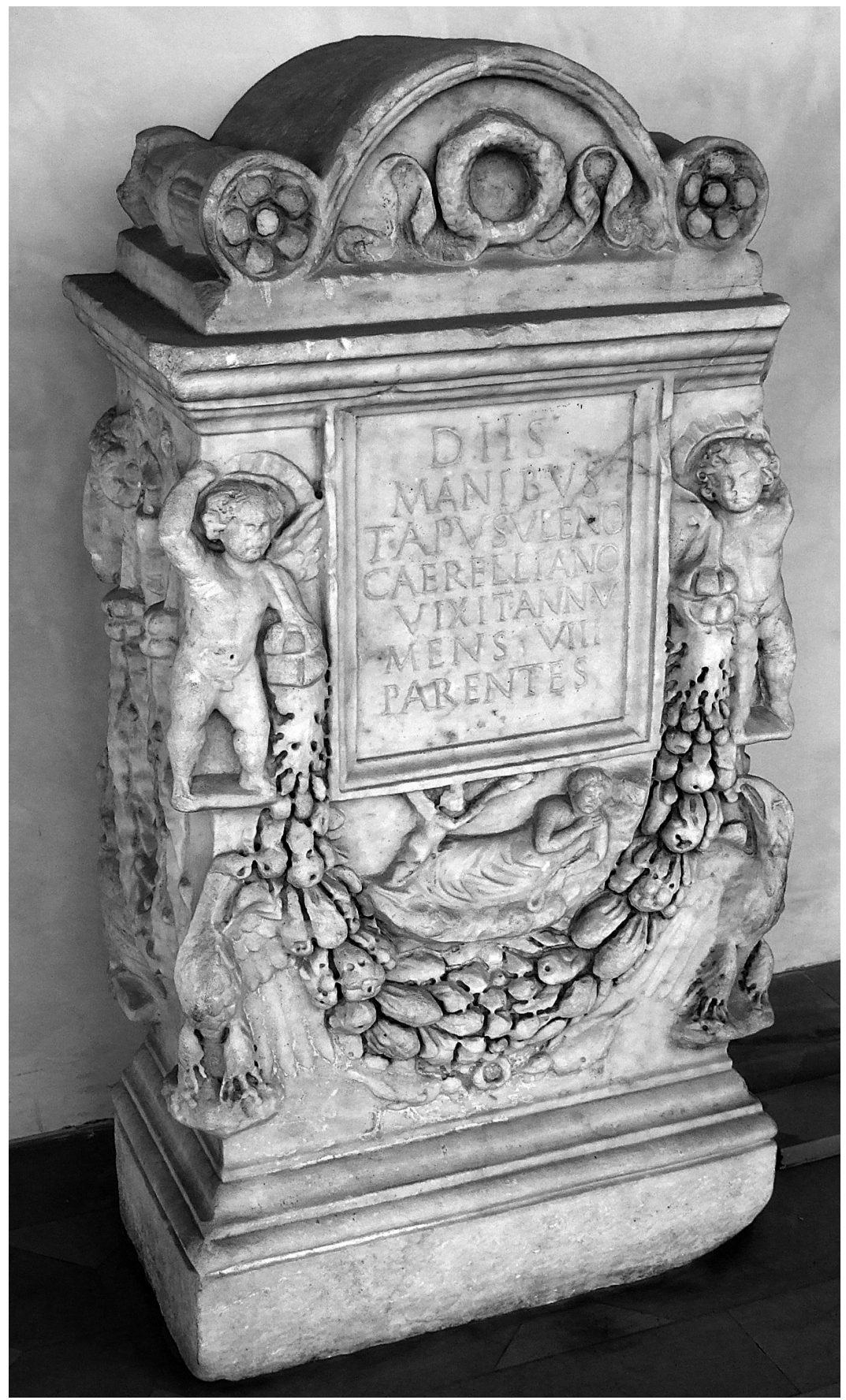

Figure 1.5: Grave altar of T. Apusulenus Caerellianus in Museo Nazionale Romano (23892) (late first century AD). Photograph: author. 
door flanked by swans on the ash chest of Lepidius Epaphra, Figure 1.1). Here too there might be garlands hanging down beside the columns, looped in a frieze across the top of the front or hanging across the field as in the garland type. The space below the inscription panel may also provide a rectangular field for the representation of a small scene - as before this may be mythological, but is just as likely to involve animals or the deceased him/herself in some way (heraldically arranged pairs of griffins and sphinxes, for example, are quite popular; see also the scene of two dogs attacking a stag in Figure 1.4 or the 'funerary banquet' of Calpurnius Beryllus in Figure 1.6). The space above the inscription panel might also provide a narrower field for decoration, often with plant or animal motifs, or again the head of Medusa - in the case of Calpurnius Beryllus's altar this is flanked by rams' heads. The sides of these monuments might be decorated with motifs such as a tree with birds, a seated griffin (see Figure 1.6) or sphinx, or the ubiquitous jug and offering bowl.

An important principle in the case of both the garland and architectonic schemes is that the design relies on a mix-and-match approach: the motifs chosen from a large and flexible repertoire are not combined into a single visibly coherent picture, and do not necessarily have any thematic connection with each other. It is debatable whether they were individually or collectively conceived of as having a 'meaning', although they did perhaps evoke associations which were seen as appropriate to the context in which they were used. ${ }^{33}$ Figured scenes play a limited part: only a small number of monuments are decorated with such scenes as the only form of decoration, and they are clearly one-off commissions where the decoration had particular meaning for the person who commissioned them (and they also tend to be late in date).$^{34}$ More commonly the figured scene is only part of and is subordinated to the decorative scheme.

33 In my view they did not form a coherent symbolic 'picture language' as advocated by Jocelyn Toynbee (Toynbee 1956): see Davies 2003.

34 For example, the scene of a woman with cupid and a little girl with birds and a dog on the ash chest of T. Apusulenus Alexander (Sinn 1987, no. 172); scenes involving cupids and boys on the ash chest of Publius Severeanus and Blolo (Sinn 1987, no. 173), both dated Claudian-Neronian; cupids wrestling in the palaestra on the ash chest of C. Minicius Gelasinus in Liverpool (Sinn 1987, no. 607 and Davies 2007, 85-90, no. 41), mid second century; battle scenes on a round urn without inscription (Sinn 1987, nos. 631); Meleager, Medea and Hippolytos/Phaedra scenes (Sinn 1987, nos. 633 and 634, 635 and 636): Sinn dates all of these urns/chests to the mid Antonine period, by which time frieze sarcophagi with similar scenes had become established. On grave altars such scenes tend to represent the deceased's work or family: L. Calpurnius Daphnus is shown at work in the Macellum Magnum on the front of his altar in the Palazzo Massimo alle Colonne (Boschung 1987, no. 953, dated between 41-110), L. Cornelius Atimetus's tool-making business and shop are shown on the sides of his altar in the Galleria Lapidaria, Vatican Museums (Boschung 1987, no. 968, dated 'soon after AD 


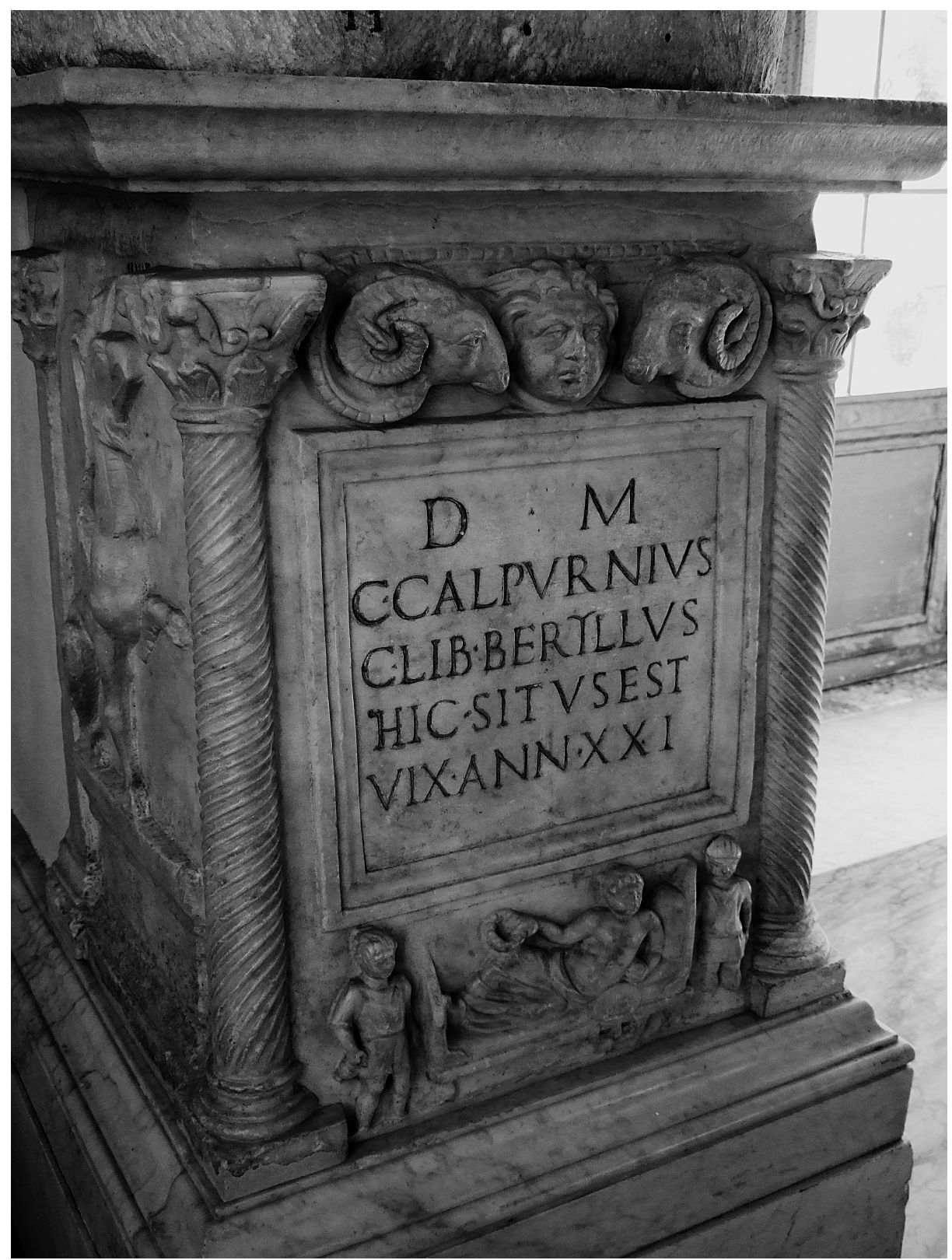

Figure 1.6: Grave altar of C. Calpurnius Beryllus in Capitoline Museums (1967) (early $2^{\text {nd }}$ century AD). Photograph: author.

80 '). Passienia Gemella is also shown with each of her two sons on the sides of her altar in Liverpool (Boschung 1987, no 329; Davies 2007,140-145, no. 104, Hadrianic). 
Broadly speaking such scenes depict either the deceased him/herself, a mythological incident, or a scene from nature. The most common of the scenes involving the deceased are the so-called funerary banquet scene, as on the grave altar of C. Calpurnius Beryllus (Figure 1.6) (the deceased is seen lying on a couch with a drinking vessel, with or without paraphernalia such as a small table standing in front of the couch with further cups on it, servants, and a spouse seated at the end of the bed), a couple linking right hands (the 'dextrarum iunctio' gesture), or, more rarely, other scenes from their working or domestic lives.

Specific mythological scenes are not very common and represent a wide range of rather disparate stories: the only mythological episodes represented on several monuments are the Rape of Persephone (Persephone/Proserpina being carried off in a chariot by Hades/Pluto) (see Figure 1.7) ${ }^{35}$ and Romulus and Remus being suckled by the she-wolf: ${ }^{36}$ otherwise scenes appear only once or twice in the surviving corpus (though Venus bathing does appear three times, ${ }^{37}$ and the doe suckling the infant Telephos was also quite popular as a pendant, or perhaps alternative, to the wolf and twins). ${ }^{38}$ The scenes which can be identified as specific mythological episodes are otherwise very disparate, and appear to be one-off special commissions: these include: Daedalus making the cow for Pasiphae, Oedipus and the sphinx, Leto fleeing with her children, the death of Archemoros, and Mercury with the infant Dionysus. ${ }^{39}$ These scenes are typically

35 Ash chest without inscription in the Museo Nazionale Romano (inv. 65197): Sinn 1987, 237, no. 603, pl. 87c (mid second century); Boschung 1987,107, no. 830, pl. 42 (beginning of second century). I know of eight other ash chests/grave altars decorated with this motif: all would appear to date to the late first/early second century.

36 It is perhaps debatable whether this should really be classed as a 'scene', as it only ever consists of the wolf and two babies, without any other figures. It is found, for example, above the garland on the front of the grave altar of Volusia Prima and Volusia Olympias, dated by consular dates to c. 90 (see note 17 above) (Buonocore 1984, 135-7, no. 106, fig. 5), and below the garland on the front of the altar of L. Volusius Urbanus (Buonocore 1984, 65-7, no. 7, fig. 1; Sinn 1990, 79-80, no. 46, pl, 133-4).

37 On the grave altar of A. Albius Graptus (Capitoline Museums 2101: Montemartini): Boschung 1987, 103, no, 763, pl. 31 (Domitianic); ash altar of M. Coelius Superstes in the British Museum 2360 (Altmann 1905, 161. no. 203, fig. 131), and on a grave altar in Nazzano.

38 The doe suckling Telephos appears on several monuments: it appears, for example, below the garland on the ash altar of L. Volusius Phaedrus (Buonocore 1984, 97-98, no. 51, fig. 4; Sinn 1990, $80-81$, no. 47, pl. 135-6). Also used on a smaller number of monuments was the similar scene of a goat suckling a child (presumably Amaltheia and Zeus): all three 'suckling' scenes (she-wolf, doe and goat) appear together on one altar, that of P. Annius Eros and Ofillia Romana in New York, Zanker, 1988.

39 Daedalus: ash chest of C. Volcacius Artemidorus, Museo Nazionale Romano inv. 125407 (Sinn 1987, 200, no. 456, pl. 70 f, late first century); Oedipus: grave altar of Ti. Claudius Geminus, lost (Altmann 1905, 105, no. 90); Leto: grave altar of 
small and involve only a few figures, and there is no obvious pattern or explanation for why they were chosen. In addition there are scenes which allude more vaguely to mythology or deities (such as Mercury watching a goat eating the leaves of a tree). ${ }^{40}$ Also quite numerous are scenes which involve the followers of Dionysus (such as the scene above the garland on the grave altar of L. Aufidius Aprilis which shows a sleeping satyr reminiscent of the Barberini Faun watched by two goats, see Figure 1.3): although these scenes sometimes include Dionysus himself, they more often show Silenus riding a donkey in the company of satyrs, maenads and/or Pan, dancing maenads, or other vignettes involving the Dionysiac thiasos. ${ }^{41}$ Other scenes involve playful cupids ${ }^{42}$ and Nereids, Tritons and other sea creatures swimming through the ocean. ${ }^{43}$

Animal scenes frequently involve combat: a lion or dogs attacking some other animal such as a deer (see Figure 1.4) and cock fights: ${ }^{44}$ usually these scenes are just presented as scenes, but in some examples, as that of the scene of two dogs attacking a deer on the ash chest of Ti. Claudius Callistus (Figure 1.4)

Luccia Telesina, Museo Chiaramonti, Vatican (Altmann 1905, 83, no. 46, pl. 47; Boschung 1987, 101, no. 732, pl. 28); Archemoros: grave altar of P. Egnatius Nicephorus, Detroit Institute of Arts 38.167 (Altmann 1905, 102, no. 84; Boschung 1987, 103, no. 765, pl. 32, Domitianic). An almost identical altar dedicated to Herbasia Clymene has been lost for so long that one wonders whether it ever actually existed: it is known only from drawings (Altmann 1905, 103, no. 85; Boschung 1987, 103, no. 766); Mercury and the infant Dionysus appear on a grave altar in Amelia and on the altar of Passiena Prima on display in the Vatican car park excavation site (where seated Mercury dangles a large bunch of grapes in front of the child, in the presence of female figures, presumably the Nymphs about to take over the task of caring for the baby).

40 Ash chest of Ianuaria from the Volusii tomb, in the Museo Gregoriano Profano: Buonocore 1984, 110-111, no. 70, fig. 42; Sinn 1987, 202-3, no. 463, pl. 72e, c. $90-$ 120; Sinn 1990, 98-9, no. 78, pl. 196-7. See also Farnoux 1960 for an elaborate and ingenious Cumont-style interpretation of the scene as an allegory of Orphic/neoPythagorean beliefs.

41 For example, the ash chest of Callityche in Bologna (Sinn 1987,161, no. 280, pl. 50b, Flavian?) with Silenus riding a donkey with satyrs, maenads and other figures.

42 Naked little boys, sometimes with, sometimes without, wings appear in a variety of different scenes. Particularly charming are those on an ash altar in the Museo Gregoriano Profano (inv. 9819): those placed under the garland on the front have just finished a cock fight - the winner approaches the prize table and the loser leaves the scene in dejection; on the right side two little boys are represented in drunken revelry, and on the left they appear with a panther (Buonocore 1984, 184-5, no. 186, figs. 37-9; Sinn 1987, 121-2, no. 119, 1. 30 a and b; Sinn 1990, 106-7, no. 93, pl. 227-32).

43 For example the grave altar of Agria Agathe in the British Museum (2350) has underneath the inscription panel a scene of a sea-centaur with a Nereid seated on its back and two cupids on its tail; on the ash chest of Flavia Sabina in the Louvre (MA 2148) a child-like sea centaur with a lyre-playing cupid on his back gallops through the waves side by side with a sea-horse (Sinn 1987, 233-4, no. 584, pl. 86b).

44 See also the scene of a lion attacking a donkey above the garland on the altar of $\mathrm{T}$. Statilius Hermes in Cambridge. For the cock fight motif see Bruneau 1965. 


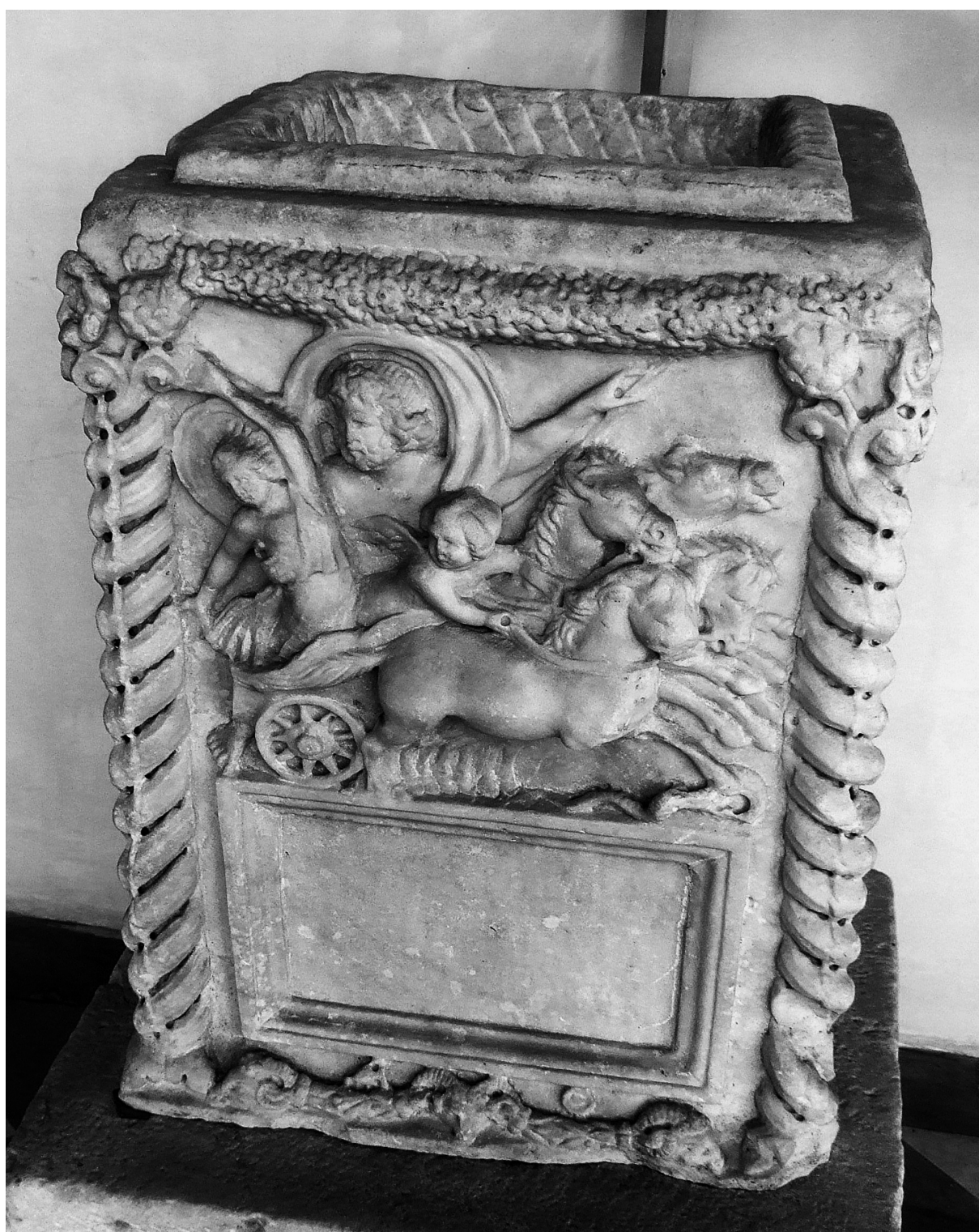

Figure 1.7: Ash chest without inscription with Rape of Persephone scene in Museo Nazionale Romano (65197) (early or mid $2^{\text {nd }}$ century AD). Photograph: author.

the group is placed on a low base, making it look like a statue group rather than a scene from nature, but this is unusual. 


\section{Schemes and themes of decoration: early sarcophagi}

The biggest coherent group of sarcophagi which appear to be made in the period before the middle of the second century are those decorated with garlands: this in itself might suggest that their decoration followed a tradition established by ash chests and grave altars and that the new form of monument did not immediately entail the introduction of radically new designs or motifs. There were however quite a number of differences in the repertoire used for garland sarcophagi compared to that used on ash chests and grave altars. The garland supports are usually human figures (especially cupids) and not bucrania or animal heads (and never the head of Zeus/Jupiter Ammon). The field is not cluttered with small birds or other subsidiary scenes or motifs: instead the fields in the lunettes above the garlands are given prominence, and are usually filled with a detailed and often quite specific mythological scene. These scenes, moreover, do not have to compete with an inscription panel for the viewer's attention: in the very few instances where these sarcophagi have an inscription it appears to have been an afterthought and is not placed in a panel but rather has had to be fitted in along the top edge of the chest, as on the sarcophagus of Ostorius Ostorianus (Figure 1.10), or between the various elements of the decoration (as on the sarcophagus of Tebanianus (Figure 1.8). ${ }^{45}$ Many motifs common on grave altars and ash chests are absent from these sarcophagi although the sculptors appear to be more inventive when it comes to composing mythological scenes their repertoire of small motifs, especially those involving birds and animals, appears to have shrunk, and they show little interest in representing the deceased him/herself in any form.

The subjects chosen for the mythological scenes on garland sarcophagi appear just as disparate (but on the whole not the same) as those used on the grave altars and ash chests but at the same time they are not the myths or mythological episodes that were to become most popular later on frieze sarcophagi. One difference however is that the larger format of the sarcophagus allows for more than one episode in a story to be shown, and several sarcophagi take advantage of this. The sarcophagus in the Metropolitan Museum, New York, dated Trajanic by Herdejürgen, has three episodes from the story of Theseus and Ariadne in the three lunettes above the garlands on the front $;^{46}$ the

45 Another early sarcophagus with the inscription fitted in along the top edge is that of Malia Titia (ASR VI, 2, 1, 109, no. 50): like that of Ostorius Ostorianus it seems it was made in Ostia. Two sarcophagi which do have central inscription panels are discussed in Herdejürgen 1990: dedicated to Volusia Prosodos and M. Aemilius Posidonianus, both are from Ostia and differ in style from Roman Metropolitan sarcophagi. It would seem that patrons in Ostia were keener on including an inscription than those in Rome itself.

46 Inv. no. 90.12: ASR VI, 2, 1, 90-92, no. 23, dated 'shortly after AD 120'; Brilliant 1984, 133-4, pl. 4.4. The three scenes (from left to right) show Theseus and Ariadne 


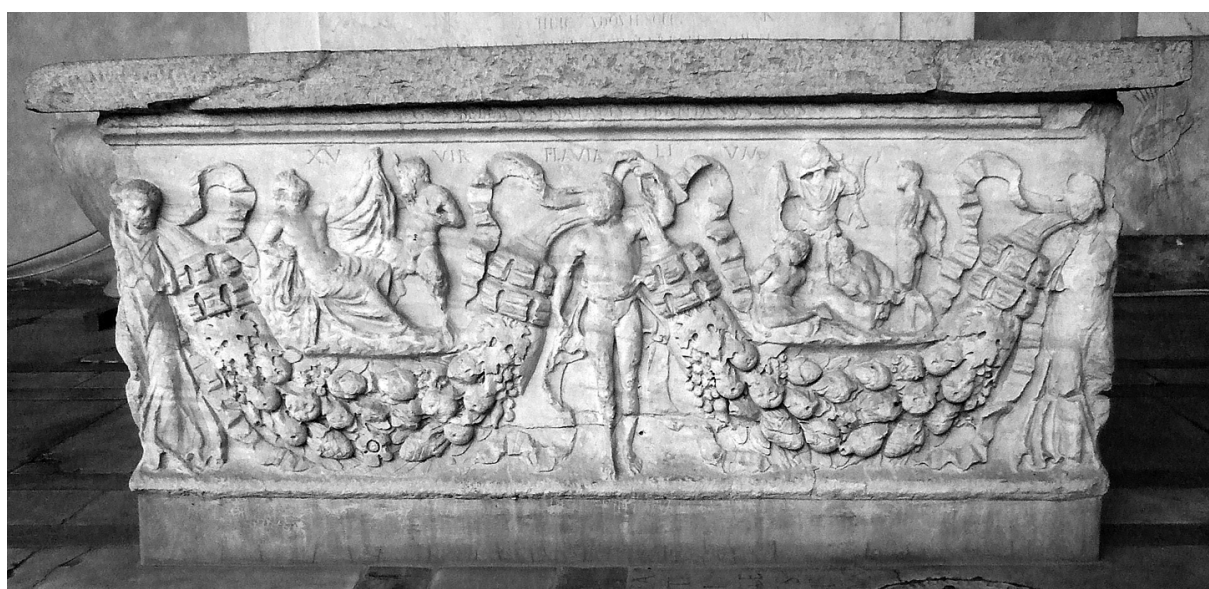

Figure 1.8: Sarcophagus of C. Bellicus Natalis Tebanianus in Pisa, Camposanto (Trajanic?). Photograph: author.

early Hadrianic sarcophagus from the same workshop in the Palazzo Barberini has three episodes from the story of the punishment of Marsyas by Apollo; ${ }^{47}$ the garland sarcophagus now in Basle has four episodes of the story of Philoctetes in the two lunettes on the front and two on the sides, ${ }^{48}$ and the well-known sarcophagus in the Louvre similarly has four episodes from the Actaeon story. ${ }^{49}$ In all of these cases the designer of the sarcophagus has taken the opportunity given by the multiple fields available to tell a story through two or more episodes using the same figures in much the same way as later sarcophagus designers were to do with frieze sarcophagi. Even the two scenes on the front of the sarcophagus of Tebanianus (Dionysus revealing himself to Pan and a trophy with two prisoners and a satyr) could be said to be linked thematically, although they are not two episodes in the same story - and the same is true of the scenes of a drunk Silenus supported by Pan and a satyr, and the sleeping Ariadne, on a sarcophagus in Liverpool. ${ }^{50}$ On the other hand the sarcophagus front in the Palazzo Mattei combines Oedipus and the sphinx with Polyphemus and Galatea, and it is difficult to see what link (if any) the viewer was expected to make between the two scenes. ${ }^{51}$ Many of the pieces surviving from this early

before the door to the labyrinth; Theseus fighting the Minotaur; Theseus abandoning Ariadne on Naxos. Above the garlands on the sides are a theatrical mask (right) and the bust of a boy (possibly Dionysus as a child) (left). The sarcophagus contained the skeleton of a man of mature years (McCann 1978, 25-9, no. 1).

47 ASR VI, 2, 1, 96-7, no. 30 (dated 120-130).

48 ASR VI, 2, 1, 85-7, no. 16 (dated 120-130).

49 ASR VI, 2, 1, 93-5, no. 26 (dated c. 130). The narrative scenes are also discussed by Brilliant (1984, 125-33, pl. 4.1-4.3).

50 Ince Blundell Hall collection: ASR VI, 2, 1, no. 42.

51 ASR VI, 2, 1, $97-8$, no. 31 (dated 120-130). 
period however are too fragmentary for us to know what other scenes they were combined with (e.g. fragments with the Rape of Persephone in Venice, Ariadne in Pisa, the childhood of Dionysus, Medea) $;^{52}$ and in addition to the sarcophagi with specific mythological scenes in the lunettes there were many with more generic scenes of the followers of Dionysus, ${ }^{53}$ Nereids and other sea creatures, ${ }^{54}$ cupids (on animals, on dolphins, with fighting cocks), ${ }^{55}$ animal scenes, bucolic scenes, ${ }^{56}$ and the ubiquitous Medusa heads. ${ }^{57}$ Masks of various kinds were also to become very popular on garland sarcophagi. ${ }^{58}$ Motifs previously popular on grave altars and ash chests, where they occur, tend to be displaced from the front onto the sides and lid, ${ }^{59}$ and even when a motif like the Rape of Persephone, relatively popular on the earlier monuments, appears on a sarcophagus it is noticeable that the sculptors were not following the same design original. ${ }^{60}$

Although garland sarcophagi would appear to represent the largest category of sarcophagus types used in the period between c. 100 and 140, other types of design were also used in the period. The largest single group is that of griffin sarcophagi, decorated usually with heraldically placed pairs of seated or standing winged griffins (which may be of the eagle-headed or lion-headed variety). A very early example is the so-called 'priest's sarcophagus' in the Vatican Museums, dated by Herdejürgen to the end of the first century: ${ }^{61}$ others include a child's sarcophagus in the Fitzwilliam Museum, Cambridge, a griffin sarcophagus from the tomb of the Licinii Crassi now in Baltimore, ${ }^{62}$ and a child's sarcophagus from Ostia (Figure 1.10). ${ }^{63}$ Another child's sarcophagus in Malibu combines

52 ASR VI, 2, 1, 99-100, no. 35 (Persephone in Venice); 96, no. 29 (Ariadne in Pisa); 127-8, no. 80 (Childhood of Dionysus, lost); 103-4, no. 40 (Medea, once in Florence).

53 Dionysiac scenes: $A S R$ VI, 2, 1, no. 46 (cupids carry a drunk Silenus).

54 Nereids and sea-creatures: $A S R$ VI, 2, 1, nos. 17, 19,22, 24, 34, 56, 70, 75.

55 Cupids riding sea-animals: $A S R$ VI, 2, 1, nos. 36, 41, 44, 53, 60, 66, 76; with fighting cocks no. 50. Cupids riding animals or sea creatures also appear in friezes on lids.

56 Animal and bucolic scenes: ASR VI, 2, 1, nos. 33, 38, 39, 50 (cock fight), 58, 59, 71.

57 Medusa Heads: ASR VI, 2, 1, nos. 15, 20, 52, 78 (from the Porta Viminalis tomb).

58 Masks: ASR VI, 2, 1, nos. 45, 46, 51, 54, 60, 61, 64.

59 This is particularly noticeable in the case of a sarcophagus once on the London art market (ASRVI, 2, 1, no. 44) with four small scenes along the front of the lid of the wolf and twins, doe and Telephos, Pan fighting cupid, and Pan confronting a goat.

60 ASR VI, 2, 1, pl. 33.1: here Persephone's body is extended almost horizontally across the picture in front of that of Hades; the usual depiction on ash chests and grave altars has Persephone's body arched back over Hades' outstretched arm (see Figure 1.7).

61 ASR VI, 2, 1, 23; the priest's sarcophagus is illustrated in Strong 1961, 47, pl. 85.

62 Cambridge sarcophagus: Huskinson 1996, 63, no. 9.12; Baltimore sarcophagus: Lehmann-Hartleben and Olsen 1942, 17-18 and 63-4; Huskinson 1996, 63, no. 9.11.

63 Sarcophagus from the Isola Sacra with inscription to Ostorius Ostorianus (Ostia Museum inv. 1156): see note 3 for references. Herdejürgen (1990, 97-8 and ASR VI, 2, 


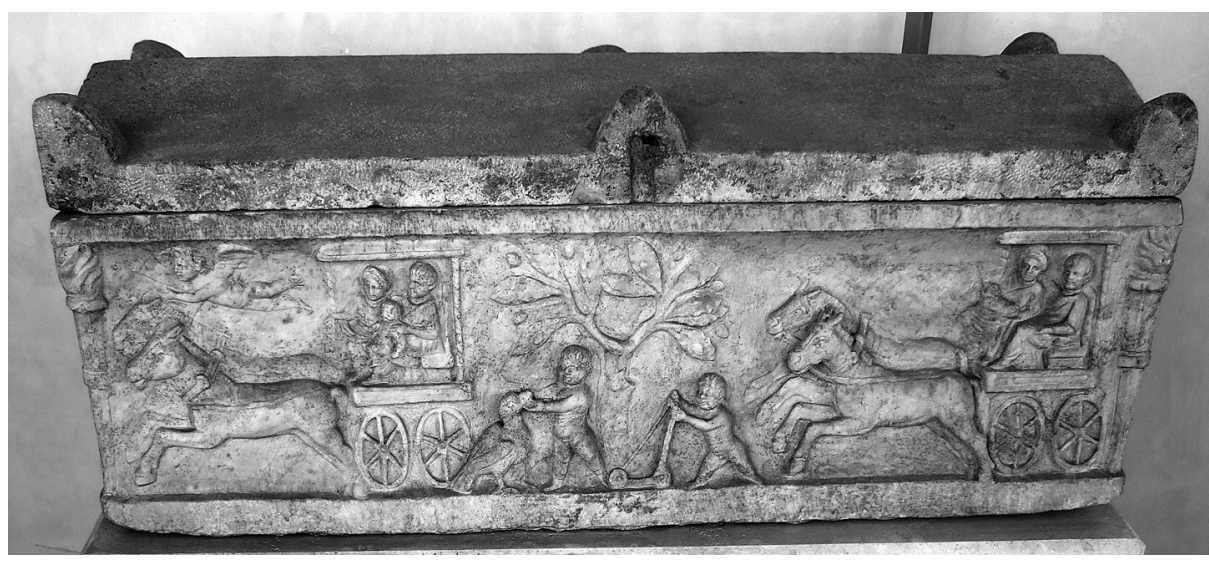

Figure 1.9: Sarcophagus in Museo Nazionale Romano (65199) with scenes of travelling carriages and children (Trajanic). Photograph: author.

four scenes of cupids pouring liquid from a jug in front of a standing griffin with two more cupids holding up the portrait bust of a girl. ${ }^{64}$ Griffins also appear on the sides of garland sarcophagi and some early strigillated sarcophagi. ${ }^{65}$ The idea of heraldically placed griffins, seated or standing either side of an object such as a tripod or incense burner, was not new: they appear on a number of ash chests and grave altars ranging in date from the reign of Tiberius to that of Hadrian, but were particularly popular at the turn of the first-second centuries. ${ }^{66}$

Also dating to the period before or around 140 is a small number of other sarcophagi, such as the one illustrated here in Figure 1.9. This shows the life course of a small child in poignant scenes of his arrival into the world in a carriage (where he is shown as a baby in his mother's arms), his progress as a toddler learning to walk and playing with a pet goose, and his early exit from the world, again in a carriage, sitting on his father's knee: that this is not an ordinary everyday journey is indicated by the cupid flying above. ${ }^{67}$ The woman's hairstyle in the two scenes dates the sarcophagus to the reign of Trajan. Another child's sarcophagus, in Agrigento, with scenes of childhood and parents mourning their

1,45 ) argues that this sarcophagus belongs to the same date (c. 130-140) and workshop as the garland sarcophagus of Malia Titia, also from Ostia.

64 Eberle 1990, figs. 1a-d.Eberle dates the sarcophagus to early in the reign of Hadrian (i. e. c. 120) and discusses its unusual iconography with reference to other griffin sarcophagi and architectural friezes from buildings in Rome, including Trajan's Forum.

65 For example, a strigillated sarcophagus at Ostia with horned lion griffins on the sides, on the left with a ram's head and on the right starting back from a snake emerging from a hole under a tree: Notizie degli Scavi 1972, 432-441 and 484-487.

66 Sinn 1987, nos. 36, 154, 164, 259, 260, 271, 298, 412, 413, 446, 550.

67 Sarcophagus in the Museo Nazionale Romano, inv. 65199: ASR I, 4, no. 190, pl. 45, where it is dated to c. 100; Huskinson 1996, 22, no. 1.29 (dated c. 120). 


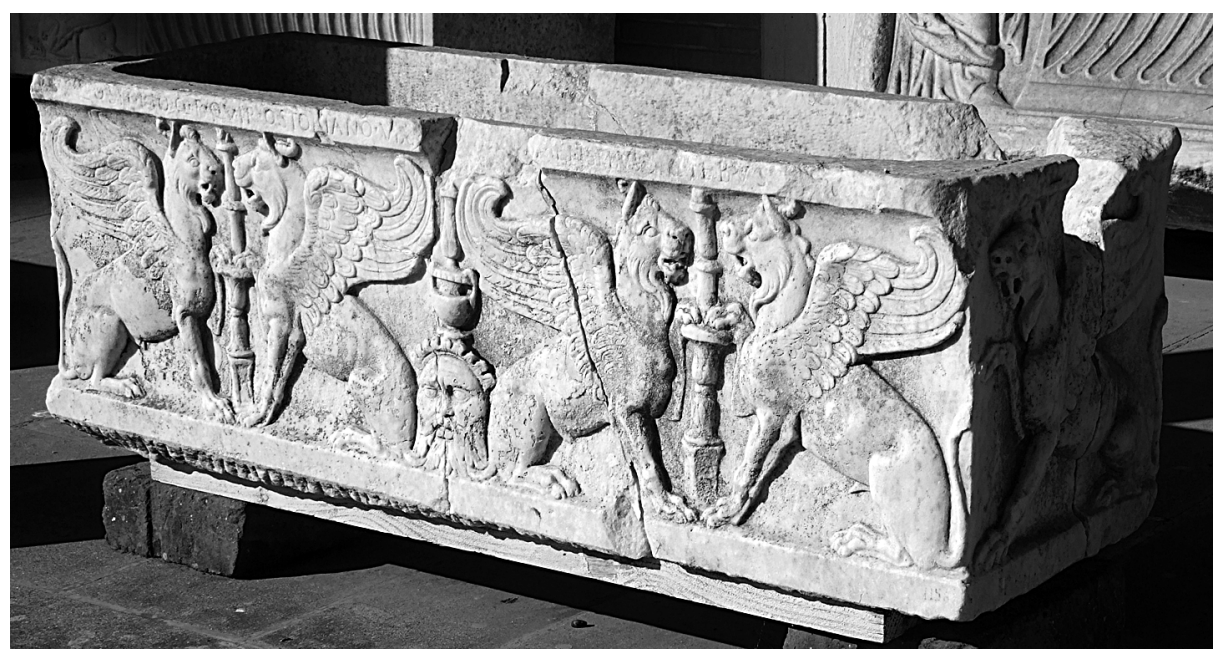

Figure 1.10: Sarcophagus of Ostorius Ostorianus decorated with griffins in Ostia (1156) (Hadrianic). Photograph: author.

child's early death, is also generally considered to be early in date (Hadrianic). ${ }^{68}$ A very small number of sarcophagi decorated with mythological scenes in a frieze that takes up the whole of the front (i.e. without garlands) may also date to the Hadrianic or very early Antonine period (140 or earlier) - for example, an Endymion sarcophagus in the Capitoline Museums. ${ }^{69}$ A small number of sarcophagi depicting Dionysus and his followers may also have been made as early as $140,{ }^{70}$ and also a few with cupids or children at play, ${ }^{71}$ but the main series of most themes seems to have started up around the middle of the second century.

This survey of the designs and motifs used on ash chests, grave altars and early sarcophagi does not point to a major shift in iconography or its meaning in the early second century, but on the other hand the repertoire used to decorate sarcophagi is not exactly the same as that found on the cremation monuments. Garland sarcophagi continue in the tradition of large grave altars

68 ASR I, 4, no. 2, pl. 53 (c. 120-130); Huskinson 1996, 20, no. 1.1 (120-130); Zanker and Ewald 2004, 66, figs. 47 and 48 (dated 130 in the caption to fig. 47 but 'Antonine' in the text).

69 Zanker and Ewald 2004, 249, fig. 221 and pp. 317-9; ASR XII, 2, no. 27.

70 A sarcophagus in the Museo Nazionale Romano with the childhood of Dionysus (inv. 124736), and a sarcophagus with the followers of Dionysus involved in various erotic activities in Naples, are both dated Hadrianic by Turcan $(1966,136)$.

71 Cupids racing in chariots: $A S R$ V, 2, 3, nos. 35 (Louvre Ma 1350), 87 (Vatican, Sala della Biga), 113 (Berlin); boys playing with nuts: ASR I, 4, no. 63 (British Museum); cupids playing: $A S R$ V, 2, 1, nos. 5 (in Berlin), 82 (Palazzo Mattei), 106 (Villa Albani). 
decorated with garlands, although with the perhaps significant omission of the prominent inscription panel. But this particular design of altar (seen in Figure $1.2,1.3$ and 1.5 ) is in the minority compared with the many other decorative schemes used on grave altars and ash chests, some of which privilege the inscription panel over all other elements of the decoration. The people who chose to buy sarcophagi and inhume their loved ones, and the sculptors who made the sarcophagi for them, seem on the whole to have had a similar mindset to those who previously bought and made grave altars, and were content to draw on a familiar repertoire of motifs, but they chose from it selectively. There appear to have been subtle shifts in emphasis as far as the iconography is concerned rather than major changes in direction. So, in the final section of this chapter I shall consider the question of whether we can deduce anything of significance about the patrons and the workshops who opted to switch from one form of funerary monument to the other, and what their motivation might have been for doing so.

\section{Patrons and sculptors}

The inscriptions usually placed on ash chests and grave altars provide a lot of information about the social groups who bought and erected these monuments: obviously only the comparatively well-off could afford to buy even a small and very ordinary sculpted marble monument, but this economic class included a wide range of social groups, including both slaves and noble families. Freedmen/ women seem to be the most prominent group, as many monuments name the deceased and/or their relatives as freed slaves, often of the imperial household. The proportion of freedmen to freeborn named in the inscriptions is unlikely to reflect the makeup of Roman society in the first and early second centuries, but it may say something about which groups were most anxious to commemorate themselves and to provide adequate and appropriate funerary provision. The find contexts of most ash chests and grave altars have not been recorded, but when we do know it would seem that many ash chests come from the large columbaria of the slaves and freedmen of the imperial family or from tombs which housed the monuments of the familia (slaves and freedmen) of other prominent Roman families. ${ }^{72}$ It is much less common to find such monuments dedicated to people who can be identified as belonging to the senatorial aristocracy, but clearly they too might be commemorated by a grave altar or have their ashes placed in a marble ash chest. The Licinii Crassi at least used

72 Such as the three columbaria of the Vigna Codini (Toynbee 1971 and 1982, 113-5), the huge columbaria on the Via Appia of the slaves and freedmen of Augustus and Livia, or the tombs of the Volusii, or the Passienii. 
grave altars as memorials to even the most prominent of their family members, as a group of nine altars found together in 1884 testifies. ${ }^{73}$ These altars are decorated in much the same way as altars to those of lower status in Roman society, although they could perhaps be said to be characterised by a degree of tasteful minimalism: they include altars decorated with garlands as well as those which put more emphasis on the inscription and confine the decoration to the pedimental area. The altar to Licinia Magna illustrated in Figure 1.2 is one of the more highly decorated altars in this group, but compared to the altar of the bronze-worker Aufidius Aprilis (Figure 1.3) it seems quite restrained, and it would seem that the noble families of Rome were not the ones to commission the most flamboyant monuments. ${ }^{74}$

The altars of the Licinii Crassi are also of interest because it would seem that this may be one instance where we can see the transition from cremation to inhumation monuments in action within a single aristocratic family. A group of sarcophagi were found in two chambers close by the place where the grave altars were found, and it has been presumed that these sarcophagi were used for the burial of the same family: the fact that the latest of the grave altars dates to about the same time as the earliest of the sarcophagi (the Hadrianic period) suggests that the family might have decided to change its usual burial habits at this time. ${ }^{75}$ However, it should be emphasised that the circumstances of the discovery and excavation make certainty that the two sets of monuments have anything to do with each other impossible, and, as is usually the case, none of the sarcophagi have inscriptions. Thus we cannot be sure that the same aristocratic family used the sarcophagi as was commemorated by the altars. But if they were, it is interesting that the first member of the family for whom the

73 The altars were found in the grounds of the Villa Bonaparte near the Porta Salaria on land which may well have been part of the family's suburban estates, but not, apparently, in their original tomb: see Kragelund 2003 esp. chapter 7, 101-8. For details of the altars and the identification of the people commemorated see also Altmann 1905, 3643; Boschung 1987, 58-9 and nos. 1, 13, 287, 593, 643, 657, 745, 856, 857; and Kragelund 2003 chapters 2, 18-45 and 8, 109-11.

74 The slaves and freedmen of the Volusii were also commemorated by conspicuously large and highly decorated ash and grave altars (catalogued and illustrated in Buonocore 1984 and Sinn 1990).

75 According to Boschung 1987, 59, no. 1.10 the last of the datable altars is that of C. Calpurnius Crassus Frugi Licinianus, who died under Hadrian; the earliest of the sarcophagi is a child's garland sarcophagus in the Museo Nazionale Romano (inv. 441; $A S R$ VI, 2, 1, 116-8, no. 60, c. 130) closely followed by a griffin sarcophagus in Baltimore (inv. 2335) (Lehmann-Hartleben and Olsen 1942 passim and Kragelund 2003). 
new burial rite was adopted was a child, and that the family no longer felt that the most important part of a funerary monument was the inscription. ${ }^{76}$

It is tempting to assume that the fashion for sarcophagi began with the Roman aristocracy and then trickled down to lower levels of society: ${ }^{77}$ after all, one of the earliest of the garland sarcophagi of the 'new' type belonged to C. Bellicus Natalis Tebanianus, a man who had been a consul, was a $X V$ vir sacris faciundis and a member of the sodalitas attached to the imperial cult of Vespasian. ${ }^{78}$ On the other hand, the flashiest grave altars commemorated wealthy freedmen and other members of the new bourgeoisie, and it is just as plausible that they might have introduced the new fashion into Roman funerary practice, a fashion that involved making larger and more expensive monuments, i.e. sarcophagi. There simply is not enough evidence to be able to say with confidence that one or another social group started the new fashion for burial in sarcophagi.

The surviving evidence does, however, suggest that the new burial practice was not (as might have been expected) the preserve of adult males: although many of the Trajanic-Hadrianic sarcophagi were made for adults a considerable number were of a size that suggests they were made for children. Iconography suitable for children was also developed early on for these sarcophagi, suggesting that there might be a positive correlation between the death of a loved child and the choice of inhumation as a burial rite, that some parents did consider inhumation a gentler and less traumatic option than cremation in such circumstances.

The amount that can be deduced about the people buried in these earliest sarcophagi is limited because of the general lack of inscriptions (and provision

76 This garland sarcophagus is designated that of a child primarily because of its size (length $1.27 \mathrm{~m}$.): Janet Huskinson in her study of Roman children's sarcophagi took size as an important criterion in defining a child's sarcophagus, with a length of $1.70 \mathrm{~m}$. as the notional maximum (Huskinson 1996, 2). She does however recognise that children might be buried in larger sarcophagi, and that smaller ones could have been designed to hold ashes or bones of adults. Only an inscription or appropriate iconography can make ascription to a child more certain. In the case of the sarcophagus under discussion (ASR VI, 2, 1, 11-8, no. 60) there is no inscription and the decoration on the front (garlands and theatrical masks) does not apply particularly to a child, but the playful cupids riding on animals on the sides could be seen as more of a pointer towards use for a child's burial.

77 Morris (1992, 54 and 59) mentions but rejects the opposite view that inhumation began among the lower orders and worked its way up through society. He concludes that 'All that we can really say is that the richer classes at Rome, from the emperors down to wealthy non-magistrates, probably all took up the new rite within the space of a generation or so, between about 140 and 180; the lower orders took to it rather more slowly' (Morris 1992, 54).

78 C.I.L. XI 1430; Arias 1977, 117-8, B4 Est. 
for inscriptions in the form of a panel) on these sarcophagi: we do not know who the Louvre Actaeon sarcophagus was commissioned for, or who built and furnished the tomb at the Porta Viminalis with its three sarcophagi, or why it was not felt necessary to inscribe the names of those buried inside on most early sarcophagi. One possible explanation is that sarcophagi were not intended to be placed in tombs with large numbers of other burials but rather in small family tombs, and each sarcophagus was expected to hold a single body: this is different from the ash chests and grave altars which were generally placed in tombs where large numbers of people were buried, often belonging to a number of different nuclear families, so that there was a need for the inscription to identify a particular monument or niche as the burial place of a an individual or a number of related individuals. This need might not be as great if the whole tomb belonged to a small family unit. But it may also be that the patrons of the earliest sarcophagi were more concerned with other issues than the commemoration of the deceased and his/her family.

One reason why these sarcophagi were not provided with space for an inscription may be due to the craftsmen who made them rather than the patrons who bought them. ${ }^{79}$ If they were not the sculptors who had previously made ash chests and grave altars but came from a different artistic tradition (e.g. immigrants from Asia Minor) they might not see the inscription panel as a central and all but indispensable element in a Roman funerary monument. ${ }^{80}$ This raises the question of who was more instrumental in defining the decorative repertoire (and monument type) in vogue at any one time: the buyers or the makers. The individual nature of some commissions suggests that the purchaser of an altar or sarcophagus did have some freedom to ask for a specific design, even something not in the sculptor's repertoire, but the formulaic nature of the majority suggests that the designs were largely dictated by the sculptors, and it seems likely that in many cases the purchaser chose from what the sculptor had in stock, or ordered from a limited selection of design options. ${ }^{81}$

79 Clearly some patrons did wish to include an inscription, but in these circumstances it had to be fitted in awkwardly around the decoration at the top of the chest (sarcophagi of Tebanianus and Malia Titia) or along the moulding at the top of the chest (sarcophagus of Ostorius Ostorianus). Herdejürgen sees the central inscription panel as a motif characteristic of provincial Italian sarcophagus production, and as an element which was only later re-introduced to Metropolitan Roman workshops - in this respect the Ostian workshops were in the forefront of Roman fashion. It is however possible that the inscription panel was reinvented in Ostia because of the wishes of the clientele there.

80 The idea that sarcophagi were introduced to Rome from Asia Minor has frequently been suggested, but without any solid evidence to back it up: the close affinities of the earliest sarcophagi with Roman grave altars would seem to me on balance to argue against such a view.

81 It is significant that Boschung's identification of workshop groups shows that particular motifs were favoured by each group, to the extent that he names the groups according to 
Nevertheless, it is perhaps more plausible that the earliest second-century sarcophagi were requested by the clients, and the artists had to adapt their repertoire to fit, rather than that the artists tried to interest their customers in a new form of monument (and its associated burial rite).

The fact that the iconographic repertoire of the Trajanic and Hadrianic garland sarcophagi largely coincides with that of at least some of the grave altars might indicate that the craftsmen who made the two types of monument came from the same artistic tradition and indeed were the same people. ${ }^{82}$ But Herdejürgen, who has carried out the most detailed assessment of the stylistic characteristics of the garland sarcophagi, is of the opinion that, as far as the sarcophagi made in Rome itself were concerned, the three workshops she has identified as making sarcophagi in the Hadrianic period were not the same as those that had previously made grave altars and ash chests. ${ }^{83}$ These sarcophagi, she suggests, rather have stylistic affinities with relief friezes from buildings, which may suggest that it was sculptors who had worked on architectural projects who began to diversify their production with the introduction of sarcophagi rather than the established workshops making ash chests and grave altars. The situation, she believes, was otherwise in Ostia, where the locally made sarcophagi have iconographic and stylistic characteristics which differentiate them from sarcophagi made in Rome, and which have greater affinities with grave altars and urns. ${ }^{84}$ One of the earliest of the sarcophagi made in an Ostian workshop is that of Malia Titia, with its scenes of cock fights in the spaces above the garlands on the front - a motif relatively common on ash chests and grave altars, but rare on sarcophagi. ${ }^{85}$

their characteristic motifs (the Medusa Group, the Tripod Group etc.): Boschung 1987, 47 and passim.

82 Specifically the larger grave altars decorated with garlands which date to the late first century: Boschung 1993, 41 remarks that it is clear that the altars of the late first century had a massive influence on the sarcophagi.

83 ASR VI, 2, 1, 33. The earliest of these three workshops (the 'Via Cassia', which made the garland sarcophagi now in New York and the Palazzo Barberini) she believes started sarcophagus production in the late Trajanic period. Although she thinks that grave altars and garland sarcophagi were not made in the same workshops she assigns the two mythological sarcophagi from the Porta Viminalis tomb to the Via Labicana workshop, which made the garland sarcophagus from the same tomb: i. e. the same workshop made different types of sarcophagi, but not grave altars and sarcophagi.

84 Herdejürgen 1990, 95-8 and 109-11; ASR VI, 2, 1, 45 and 68. She estimates that production of garland sarcophagi at Ostia began in the 130s (earlier examples found at Ostia were made in Roman workshops).

85 The closest parallel for these scenes is the scene below the garland on a large ash chest from the Tomb of the Volusii, now in the Museo Gregoriano Profano: Sinn 1991, $106-7$, no. 93 . 


\section{Conclusion}

If one compares a cremation monument of the mid first century (such as that of Lepidius Epaphra illustrated in Figure 1.1) with any typical frieze sarcophagus of the mid second century (such as the 'Pianabella' Iliad sarcophagus, Figure 2.1) there appear to be quite considerable differences between them in form, iconography and purpose. It is not unreasonable to deduce that there must have been a considerable shift in mentality over the course of this hundred-year period, nor is it implausible that the change from cremation to inhumation was in some way related to this shift. But a more nuanced analysis of the monuments reveals that this was a gradual process and suggests that the attitudes that produced some of the more elaborate grave altars of the last two decades of the first century were not so very different from those that resulted in the earliest sarcophagi. The motifs used on the early second-century sarcophagi such as garlands, cupids, medusa heads, mythological scenes, griffins, and even scenes of childhood ${ }^{86}$ were used on grave altars before they were used on sarcophagi, but the iconographic repertoire used on these sarcophagi is more limited and their decorative schemes have subtly different emphases. We do not know for certain that the same kinds of people bought these monuments: the evidence does not point to any particular social group being at the forefront of the move towards inhumation and the use of richly decorated sarcophagi, except in so far as the people concerned must have been wealthy.

We can at least be sure that large and showy grave altars and the earliest sarcophagi were not reserved for the most important people in Roman society (mature male citizens), although they were used for them: they were also used for both women and children. ${ }^{87}$ It may be that Romans at the turn of the first/ second centuries were beginning to find the cremation of loved ones too traumatic an experience to bear, as is suggested by Statius in his description of Abascantus's abhorrence of cremation for his wife Priscilla's corpse - she was therefore inhumed. ${ }^{88}$ Pliny the Younger also describes the extravagant (and in Pliny's view unseemly) mourning of Regulus for his dead son: the boy was apparently cremated, but the incident reveals the depths of feeling that could be generated at the death of a child in Roman society at precisely the period when sarcophagi were beginning to be used. ${ }^{89}$ Many of the early sarcophagi are in sizes

86 Childhood scenes are not common on grave altars and ash chests, but are found for example on the altar of C. Iulius Philetus in the Vatican Museums (Museo Gregoriano Profano 9934): Sinn 1990, 65-7, no. 33, pl. 96-9 (Tiberian-Caligulan).

87 E.g. the grave altars of Licinia Magna (Figure 1.2) and T. Apusulenus Caerellianus (Figure 1.5): the latter commemorates a boy who died aged five years and eight months, and was dedicated by his parents (CIL VI 38027).

88 Silvae 5.1.226-7.

89 Pliny, Letters 4.2 and 4.7. 
appropriate to the burial of a child who has not yet reached adult stature. Sentimental impulses on the part of the bereaved husband or parent may explain the decision to inhume the loved one's body in a sarcophagus in some cases, and can therefore be seen as one factor in the changes in funerary practice, but it does not explain everything. When looking back from the perspective of the mid-Antonine sarcophagi a crucial development appears to be the expansion of the mythological subject matter, seen in the range of the myths represented, the amount of space dedicated to them, and sophistication of the narrative techniques used. But were sarcophagi introduced to Rome in order to provide the scope for such developments? This does not seem likely. It does not seem to me that Tebanianus's sarcophagus (Figure 1.8) is designed to communicate ideas essentially different from those presented by the grave altar of Aufidius Aprilis (Figure 1.3): it is not clear in either case why the Dionysiac scenes were thought to be appropriate, any more than it is evident why Aprilis was cremated and Tebanianus was inhumed. ${ }^{90}$ It was only after sarcophagi had begun to be used in Rome as more than an occasional anomaly that the possibilities this form of monument presented for the representation of myth was fully realised - and from the sculptors' point of view the combination of sarcophagus and myth provided excellent opportunities for the expansion of their production in a no doubt very lucrative direction.

\section{Bibliography}

Altmann, W. Die römischen Grabaltäre der Kaiserzeit (Berlin, 1905).

Amedick, R. Vita Privata auf Sarkophagen. Die Sarkophage mit Darstellungen aus dem Menschenleben (ASR 1.4) (Berlin, 1991).

Arias, P.E., Gabba, E., and Cristiani, E. Camposanto Monumentale di Pisa 1: Le Antichità (Pisa, 1977).

Bérard, C. Silène porte-van. Bull. Ass. Pro Aventico 22 (1974), 5-16.

Boschung, D. Antiken Grabaltäre aus den Nekropolen Roms (Acta Bernensia 10) (Bern, 1987).

Boschung, D. Grabaltäre mit Girlanden und früher Girlandensarkophage, Zur Genese der kaiserzeitlichen Sepulkralkunst, in: Grabeskunst der römischen Kaiserzeit, edited by G. Koch (Mainz, 1993), 37-42.

Brilliant, R. Visual Narratives. Storytelling in Etruscan and Roman Art (Ithaca and London, 1984).

Bruneaux, P. Le motif des coqs affrontés dans l'imagerie antique. Bulletin de Correspondance Hellenique 89 (1965), 90-121.

90 Turcan $(1999,102)$ attempts to relate the trophy scene on Tebanianus' sarcophagus with possible events in the deceased's life by suggesting that he took part in Trajan's Parthian War: thus the Indian Triumph of Dionysus, the civilising god, could be equated to the Roman imperialist mission, and Tebanianus is himself equated with the deity and merits apotheosis. 
Buonocore, M. Schiavi e Liberti dei Volusi Saturnini. Le iscrizioni del colombario sulla via Appia antica (Rome, 1984).

Calza, R. Un Nuovo Sarcophago Ostiense. Bollettino d'Arte 39 (1954), 107-113.

Caronna, E.L. Notizie degli Scavi 29 (1975), 205-222.

Cumont, F. Recherches sur le symbolisme funéraire des romains (Paris, 1942).

Davies, G. Roman funerary symbolism in the early Empire, in: Inhabiting Symbols. Symbol and image in the ancient Mediterranean (Accordia Specialist Studies on the Mediterranean vol. 5), edited by J.B. Wilkins and E. Herring (London, 2003), $211-222$.

Davies, G. The Ince Blundell Collection of Classical Sculpture Volume 2: The ash chests and other funerary reliefs (Mainz am Rhein, 2007).

Eberle, A. F. Un sarcophage d'enfant au J. Paul Getty Museum, in: Roman Funerary Monuments in the J. Paul Getty Museum vol. 1, edited by M. True and G. Koch (California, 1990), 47-58.

Farnoux, B. Combet. L'inspiration pythagoricienne et dionysiaque dans un autel funéraire du Musée du Latran. Mélanges de l'École française de Rome, Antiquité 72 (1960), $147-165$.

Herdejürgen, H. Girlandensarkophage aus Ostia, in: Roman Funerary Monuments in the J. Paul Getty Museum vol. 1, edited by M. True and G. Koch (California, 1990), 95-114.

Honroth, M. Die Stadtrömische Girlanden (Sonderschriften of the Österreichischen Archäologischen Institut in Wien no. 17) (Vienna, 1971).

Huskinson, J. Roman Children's Sarcophagi. Their decoration and social significance (Oxford, 1996).

Kragelund, P., Moltesen, M. and Østergaard, J. The Licinian Tomb. Fact or Fiction? (Copenhagen, 2003).

Kleiner, D.E.E. Roman Imperial Funerary Altars with Portraits (Rome, 1987).

McCann, A.M. Roman Sarcophagi in the Metropolitan Museum of Art (New York, 1978).

Morris, I. Death-Ritual and Social Structure in Classical Antiquity (Cambridge, 1992).

Nock, A. D. Cremation and Burial in the Roman Empire. Harvard Theological Review 25.4 (1932), $321-359$.

Nock, A. D. Sarcophagi and Symbolism. American Journal of Archaeology 50.1 (1946), $140-170$.

Panciera, S. Notizie degli Scavi 29 (1975), 222-232.

Roller, M. B. Dining Posture in Ancient Rome. Bodies, values and status (Princeton and Oxford, 2006).

Sinn, F. Stadtrömische Marmorurnen (Mainz am Rhein, 1987).

Sinn, F. Vatikanischen Museen Museo Gregoriano Profano ex Lateranense: Die Grabdenkmäler 1 Reliefs Altäre Urnen (Mainz am Rhein, 1990).

Strong, D.E. Roman Imperial Sculpture (London, 1961).

Toynbee, J. M. C. The Hadrianic School. A chapter in the history of Greek art (Cambridge, 1934).

Toynbee, J. M. C. Picture-language in Roman Art and Coinage, in: Essays in Roman Coinage presented to Harold Mattingly edited by R. A. G. Carson and C. H. V. Sutherland (Oxford, 1956), 205-226.

Toynbee, J. M. C. Death and Burial in the Roman World (London and Southampton, 1971 and 1982).

Turcan, R. Les sarcophages romains à representations Dionysiaques (Paris, 1966).

Turcan, R. Messages d'outre-tombe. L'iconographie des sarcophages romains (Paris, 1999). 
Zanker, P. Bilderzwang: Augustan Political Symbolism in the Private Sphere, in: Image and Mystery in the Roman World, Papers given in memory of Jocelyn Toynbee, edited by J. Huskinson, M. Beard and J. Reynolds (Gloucester, 1988), 1-20.

Zanker, P. and Ewald, B. C. Mit Mythen leben. Die Bilderwelt der römischen Sarkophage (Munich, 2004). 
